\title{
Use of swine wastewater in oilseed radish crop: agronomic and environmental aspects
}

\section{Uso de água residuária da suinocultura no cultivo de nabo forrageiro: aspectos agronômicos e ambientais}

\author{
Thaisa Pegoraro ${ }^{1 *}$; Silvio César Sampaioº; Maria Hermínia Ferreira Tavares²; \\ Silvia Renata Machado Coelho²; Leocir José Carneiro ${ }^{1}$; Denise Palma \\ Carlos Henrique Wachholz Souza ${ }^{3}$; João Batista Guerra ${ }^{3}$
}

\begin{abstract}
Swine effluent has been applied to soils to promote nutrient cycling and reduce the uncontrolled disposal of effluents into bodies of water. However, the use of these effluents on various crops has raised environmental and public health concerns. Oilseed radish crop (Raphanus sativus L.) is a winter crop planted in no-tillage systems as a green fertilizer that also can be used for biodiesel, and it requires high levels of nutrients for its development. Thus, the present study aimed to evaluate the environmental and agronomic effects of the application of swine wastewater on oilseed radish. The experiment was conducted in a 0.162 ha area with the following treatments: unirrigated (rainfed), irrigated, and fertilized with swine wastewater $\left(370 \mathrm{~m}^{3} \mathrm{ha}^{-1} \mathrm{cycle}^{-1}\right)$. After each rainfall event, analyses were conducted for the main macro and micronutrients in the runoff and percolated material from drainage lysimeters. Changes in the physical and chemical characteristics of the soil were also analyzed, as were the agronomic and nutritional indices of the dry crop phytomass in full blooming stage. Application of swine wastewater at a level of $370 \mathrm{~m}^{3} \mathrm{ha}^{-1}$ produces a crop with better agronomic quality. Over the long term, however, caution should be taken regarding the surface runoff of $\mathrm{NO}_{3}^{-}, \mathrm{P}, \mathrm{K}, \mathrm{Mn}$ and total salts and the percolation of $\mathrm{NO}_{3}^{-}, \mathrm{Na}$ and $\mathrm{Cu}$. Moreover, the rainfall occurred one day after fertigation contributed to the increase of the levels of $\mathrm{P}, \mathrm{K}, \mathrm{Na}, \mathrm{Cu}, \mathrm{Zn}$ and $\mathrm{Mn}$ in the percolated material.
\end{abstract}

Key words: Water reuse, nonpoint pollution, biomass, energetic crop

\section{Resumo}

O efluente oriundo da suinocultura tem sido aplicado no solo com o intuito de promover a ciclagem de nutrientes e como uma saída à disposição final desses efluentes, sem controle, em corpos hídricos. Entretanto, o reúso de efluentes nas mais diversas culturas preocupa com relação à possibilidade de gerar impactos ambientais e, consequentemente, à saúde da população. O nabo forrageiro (Raphanus sativus L.) é uma cultura utilizada como adubo verde de inverno no plantio direto e pode ser usado para a produção de biodiesel, sendo exigente em nutrientes para o seu desenvolvimento. Desse modo, objetivou-se avaliar os efeitos ambientais e agronômicos da aplicação de água residuária da suinocultura no cultivo de nabo forrageiro. O experimento foi instalado em área de 0,162 ha e os tratamentos utilizados foram sem irrigação (sequeiro), irrigado e fertigado com água residuária da suinocultura $\left(370 \mathrm{~m}^{3} \mathrm{ha}^{-1}\right.$

\footnotetext{
${ }^{1}$ Discentes do Programa de Doutorado em Engenharia Agrícola, Universidade Estadual do Oeste do Paraná, UNIOESTE, Cascavel, PR, Brasil. E-mail: thaisapegoraro@gmail.com; leocir_jcarneiro@yahoo.com.br; palmadenise@yahoo.com.br

2 Profs., UNIOESTE, Cascavel, PR, Brasil. E-mail: silvio.sampaio@unioeste.br; mhstavar@unioeste.br; silvia.coelho@unioeste. br

${ }^{3}$ Mestres em Engenharia Agrícola da UNIOESTE, Cascavel, PR, Brasil. E-mail: carlos_hws@hotmail.com; add_guerra@yahoo. com.br

* Author for correspondence
} 
ciclo $\left.^{-1}\right)$. Após cada chuva foram realizadas análises dos principais macro e micronutrientes no material escoado e percolado, provenientes de lisímetros de drenagem. $\mathrm{O}$ solo foi analisado quanto às possíveis alterações das características físicas e químicas e, no vegetal, avaliaram-se os índices agronômicos e nutricionais presentes na fitomassa seca em completo estágio de floração. A aplicação de água residuária da suinocultura (ARS) em uma taxa de $370 \mathrm{~m}^{3} \mathrm{ha}^{-1}$ acarretou maior qualidade agronômica da cultura. Porém, em longo prazo, deve-se ter cuidado com o escoamento superficial de $\mathrm{NO}_{3}^{-}, \mathrm{P}, \mathrm{K}, \mathrm{Mn}$ e sais totais e a percolação de $\mathrm{NO}_{3}^{-}, \mathrm{Na}$ e $\mathrm{Cu}$. Além disso, a precipitação pluvial ocorrida um dia após a aplicação de ARS contribuiu para o aumento das concentrações de $\mathrm{P}, \mathrm{K}, \mathrm{Na}, \mathrm{Cu}, \mathrm{Zn}$ e $\mathrm{Mn}$ no material percolado.

Palavras-chave: Reúso de água, poluição difusa, biomassa, cultura energética

\section{Introduction}

The application of waste and effluents generated from livestock activities on agricultural soils may be an efficient method of promoting nutrient cycling, particularly for nitrogen, phosphorus and potassium. This practice allows the farmer to minimize the costs with conventional fertilizers and provides an alternative to the raw discharge of residues generated from extensive poultry, beef and pork productions, allowing soil and plants to be used as filters.

The excess of nutrients in the soil and water has become a problem in various regions in Brazil. The south region of Brazil produces in general 8.6 liters of waste (liquid and solid residues) by pork a day, depending on the productive phase. All that waste has to be applied on soil as an agricultural reuse to avoid direct pollution in the water bodies, since they do not receive proper treatment to be disposed (DARTORA et al., 1998). Studies have reported the application of swine effluents in different soil conditions: on crops such as maize (CERETTA et al., 2005), soybean (MAGGI et al., 2011), passion fruit (CRUZ et al., 2008), beans (COSTA et al., 2007; DOBLINSKI et al., 2010) and lettuce (BAUMGARTNER et al., 2007); in natural grazing conditions (DURIGON et al., 2002; GATIBONI et al., 2008); with forage grasses (SMITH et al., 2007); and in no-tillage planting systems (BASSO et al., 2005; BERTOL et al., 2005; CERETTA et al., 2005). Studies on the use of agricultural effluents in the cultivation of oilseed radish (Raphanus sativus L.) deserve attention, because it is an energetic crop that grows easily and can provide income to the farmers who might sell the seeds to biofuel production. The crop has been used in Brazil as a green manure for no-tillage planting systems during the winter. It provides large quantities of hay for notillage planting, has a considerable nutrient cycling capacity and acts as an excellent soil cover during the transition between maize and wheat (CALEGARI et al., 1993). Ceretta et al. (2005) and Basso et al. (2005) have observed that oilseed radish, along with oats, is one of the crops with the least nonpoint source pollution potential, reducing percolation and surface runoff of nitrogen and phosphorus.

Furthermore, the introduction of biodiesel to the energy matrix in Brazil by mandatory blending of biofuels with mineral diesel oil (BRASIL, 2005) has opened new business opportunities for large and small farmers. Recently studied energy crops include soybean, coconut, castor bean, physic nut, palm oil, canola oil, babassu oil and cotton, among others. Oil levels in the oilseed radish seeds can vary between 30\% (SILVA; FREITAS, 2008) and $54 \%$ (DOMINGOS et al., 2008) of the seed weight, higher than several of the crops mentioned above.

Therefore, there is great promise in the use of agricultural effluents on crops that promote the cycling of nutrients present in these effluents, which meet environmental concerns and energetic potential. Thus, the objective of this study was to evaluate the effects of the application of swine wastewater on oilseed radish on the parameters: physical and chemical soil properties; agronomic crop yield; accumulation of nutrients in the 
phytomass; and percolation and runoff of nutrients to water ponds.

\section{Materials and Methods}

Location, materials and experimental management

The trial was conducted in an experimental area at Cascavel city, in Brazil (24.53'S and $53^{\circ} 23^{\prime} \mathrm{W}$ ) with an altitude of $682 \mathrm{~m}$. The soil is classified as Rhodic Hapludox (SOIL SURVEY STAFF, 1999) and the climate is classified as mesothermic humid subtropical Cfa (Köppen). The average annual rainfall is 1,800 to $2,000 \mathrm{~mm}$, the average temperature is $20{ }^{\circ} \mathrm{C}$ and the relative air humidity is between 75 and $80 \%$ (IAPAR, 2000). Meteorological data (temperature and rainfall) were provided by the Paraná Meteorological System (Simepar) (Figure 1).

Figure 1. Precipitation ( $\mathrm{mm}$ ) and percolation volumes (L) during the field experiment with oilseed radish crop in rainfed (T1), irrigated (T2) and fertilized with swine wastewater (T3) treatments.

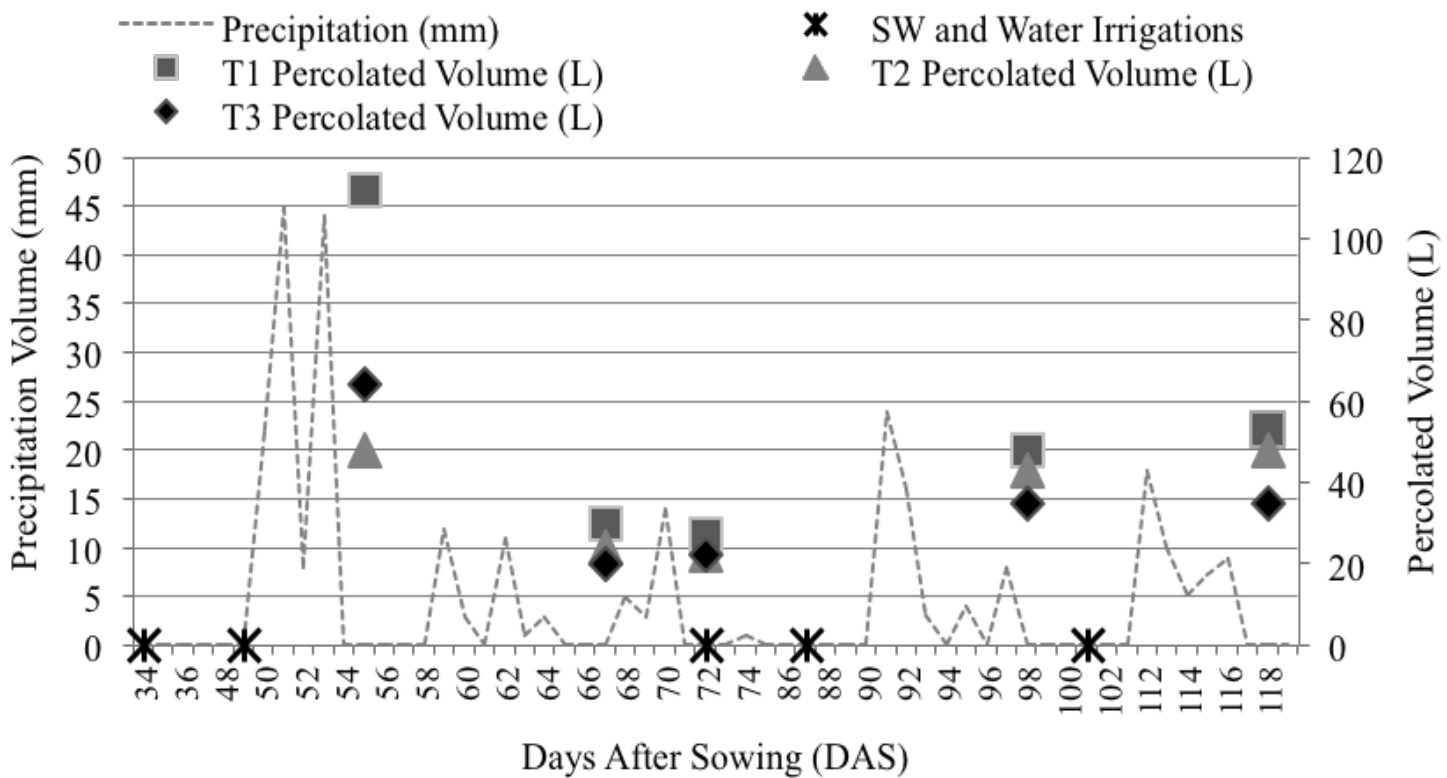

Source: SIMEPAR and author's elaboration.

The experimental area had 0.162 ha and was divided into three parcels of $540 \mathrm{~m}^{2}$ each, representing three treatments defined by irrigation type: rainfed (T1), irrigated (T2) and fertigated with swine wastewater (SW) (T3). Three experimental field plots were established on $8-9 \%$ slope for treatment, which represented three repetitions measuring 12 x $15 \mathrm{~m}$ each $\left(180 \mathrm{~m}^{2}\right)$. Two independent $15 \mathrm{~m}^{3}$ reservoirs containing either water or SW were used for irrigation. The effluents and the water were distributed in the same amount onto the experimental area by a sprinkler irrigation system. The irrigation system installed over the parcels had a smaller spacing $(6 \times 12 \mathrm{~m})$ than the parcels and consisted of a $6 \mathrm{CV}$ motor-pump, 5.08 $\mathrm{cm}$ tubing and 16 Kadox (model IR-1612F) plastic full circle sprinklers with one nozzle and a flow of approximately $1,200 \mathrm{~L} \mathrm{~h}^{-1}$. The experimental area was dried out using $20 \mathrm{~L} \mathrm{ha}^{-1}$ glyphosate (Roundup) dose twenty days before crop sowing and cleaned by manual ploughing. The CATI AL 1000 oilseed radish cultivar was sown in May 2009 by throwing, with sowing density of $27 \mathrm{~kg} \mathrm{ha}^{-1}$.

Topdressing fertilizers were unnecessary and cultural treatments were not employed. The growing 
cycle of oilseed radish was approximately 125 days, and the harvest was manually collected using sickles. For evaluation of yield all the material in the plots was removed, the plant debris were airdried and the grains were separated manually.

\section{Soil and effluent characterization}

Soil sampling and chemical characterization were conducted before the experiment was installed (Table 1) and after the crop was in full bloom in the field (Table 2), at a depth of 0-20 cm, according to methods described by Olsen and Sommers (1982), Embrapa (1997) and Raij et al. (2001).

Macroporosity (MAP), microporosity (MIP) and total porosity (TP) were analyzed by the tension table method, and soil bulk density (Ds) was analyzed by the volumetric ring method; samples were taken before (April/2009) and after setting up the experiment (November/2009), according to the methodology of Embrapa (1997). Three undisturbed soil samples were collected in triplicate for each parcel, at depths of 0-10, 10-20 and 20-30 cm, for a total of 81 samples for each collection.

The SW was obtained from an effluent stabilization pond from the biodigester output in a pork farm with complete life cycle (from farrow to finish stage). Water and SW were applied at a dosage of $370 \mathrm{~m}^{3} \mathrm{ha}^{-1}$ for the entire cycle of the culture divided in five biweekly irrigations at 34 , 49, 72, 87 and 101 days after sowing (DAS) (Figure 1). The water and SW were analyzed according to the American Public Health Association (1998) (Table 1).

Table 1. Characterization of the soil before the experiment set up, water (T2) and SW (T3) applied.

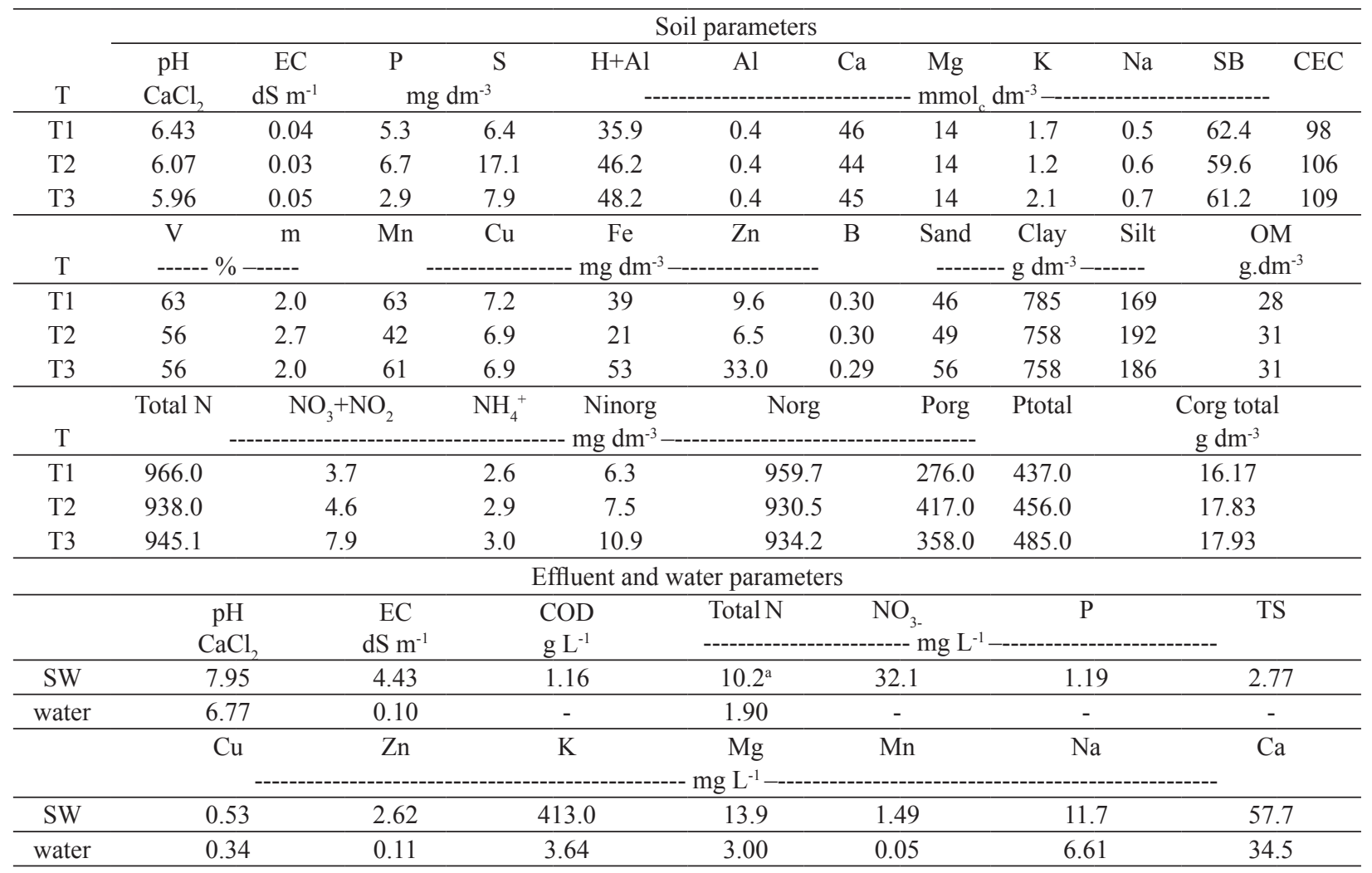

${ }^{a} \mathrm{~N}$ total expressed in $\mathrm{g} \mathrm{L}^{-1}$; T: treatments; T1: rainfed; T2: irrigated; T3: fertilized; SW: swine wastewater; EC: electric conductivity; $\mathrm{H}+\mathrm{Al}$ : potential acidity; CEC: cation exchange capacity; V: base saturation; m: Al saturation; COD: chemical oxygen demand; TS: total solids.

Source: Elaboration of the authors. 
Table 2. Chemical soil analysis after full bloom of oilseed radish crop in rainfed (T1), irrigated (T2) and fertilized with swine wastewater (T3) treatments.

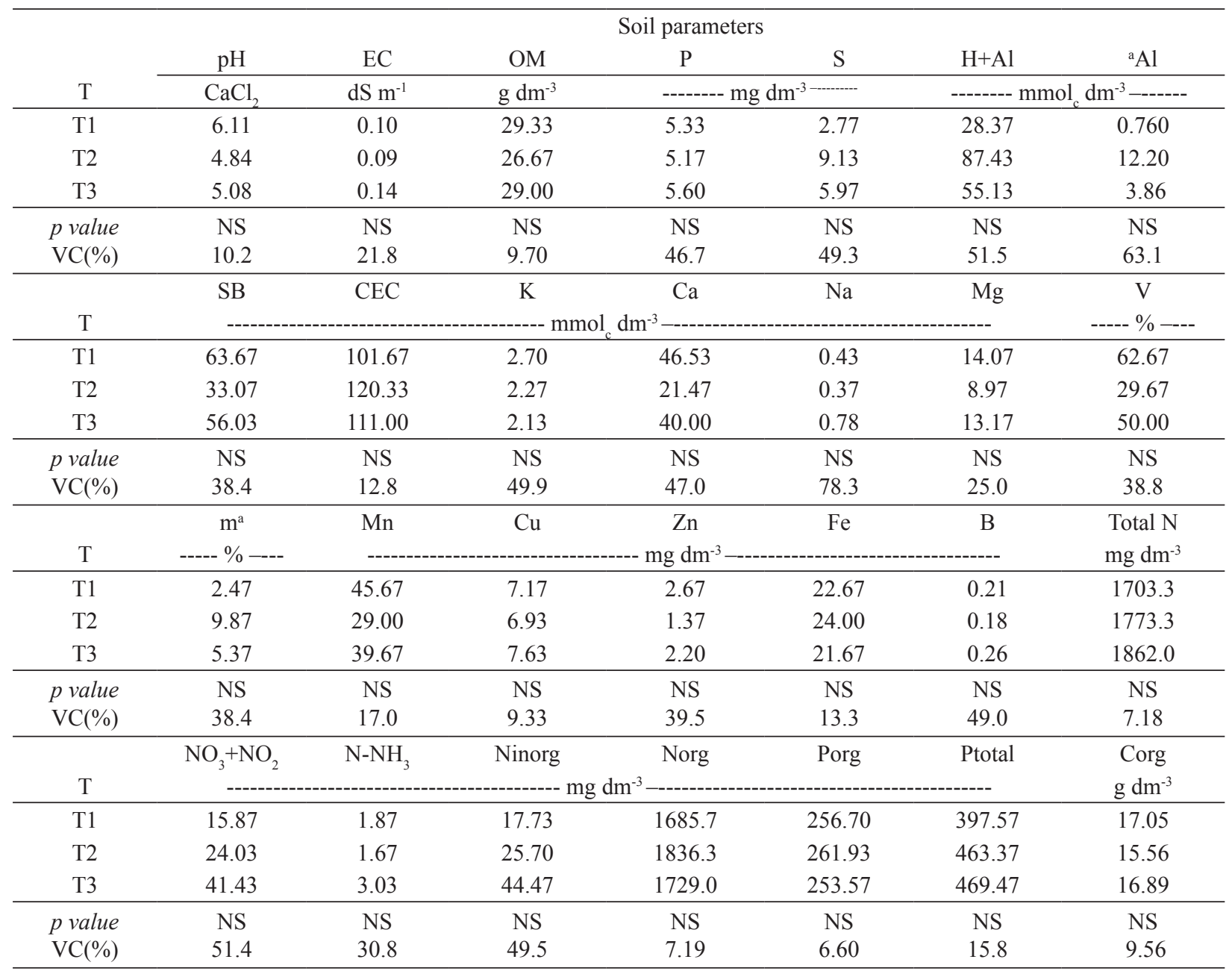

${ }^{a}$ Box-Cox transformation was used. T: treatments; EC: Electric conductivity; OM: organic material; SB: sum of bases; CEC: cation exchange capacity; V\%: base saturation; $\mathrm{m} \%$ : Al saturation.

Source: Elaboration of the authors.

\section{Biomass and agronomic indices}

When the oilseed radish crop was in full bloom, a $0.16 \mathrm{~m}^{2}$ quadrant was randomly thrown into the field, and three subsamples of plant materials in each plot were collected, resulting in nine repetitions per treatment. The following measures were taken: plant height $(\mathrm{PH})$, root system length (RL), basal diameter (BD) and number of plants per area $\left(\mathrm{m}^{2}\right)(\mathrm{NP})$. In the laboratory, the root volume (RV) was determined by liquid displacement after immersing the root system in a graduated cylinder containing $70 \%$ water and $30 \%$ ethanol; the foliar area (FA) was determined by a gravimetric analysis (BENINCASA, 2003). Shoot dry matter (SDM) and root dry matter $(\mathrm{RDM})$ were obtained after drying in an air forced incubator at $60^{\circ} \mathrm{C}$ until constant mass was obtained.

Samples of the SDM were ground (10-mesh) to determine the concentrations of nutrient $(\mathrm{N}, \mathrm{P}, \mathrm{K}$, $\mathrm{Ca}, \mathrm{Mg}, \mathrm{S}, \mathrm{Fe}, \mathrm{Mn}, \mathrm{Zn}, \mathrm{Cu}$ and B) (MALAVOLTA; VITTI; OLIVEIRA, 1997).

At the end of the oilseed radish growing cycle, 100 pods per repetition were counted to determine 
the number of grains per pod $(\mathrm{NG})$. The grain productivity (GP) was evaluated after hulling the pods collected in each of the three $180 \mathrm{~m}^{2}$ plots per treatment, correcting to $13 \%$ of humidity and the values were extrapolated to $\mathrm{kg} \mathrm{ha}^{-1}$.

\section{Nutrient losses by runoff and percolation}

There were three glass fiber drainage lysimeters in each plot of the study area, resulting in three lysimeters by treatment, with a capacity of $1 \mathrm{~m}^{3}$, depth of $1.10 \mathrm{~m}$, diameter of $1.43 \mathrm{~m}$ and an area of $1.60 \mathrm{~m}^{2}$ which were installed according to Aboukhaled, Alfaro and Smith (1986). Briefly, the soil was excavated from the area and it was installed PVC tubes of $15 \mathrm{~m}$ length and $25 \mathrm{~mm}$ diameter on the bottom. A faucet was connected at the end of the PVC tube to control the percolated material, which was measured after every raining event. Inside the lysimeter, a net was put over the draining whole to avoid clogging and $0.1 \mathrm{~m}$ of crushed stone was added to better drain the leachate. A polyester blanket was placed over the stones to separate it from the soil layers, which were put back in the upside order of the initial digging. Each soil layer was lightly compacted and all the lysimeters were daily irrigated in order to provide saturation and settling of the soil. Besides that, each lysimeter had a $10 \mathrm{~cm}$ edge over the soil and a whole connected to a faucet and a $5 \mathrm{~L}$ gallon to collect the runnof. Five collections of percolated $(55,67,72,98$ and 118 DAS) were taken after one day of the precipitation events which occurred among 50-53, 59-65, 68-70, 90-97 and 112-116 DAS (Figure 1). The precipitation volumes were, respectively, 118.2, 28.8, 21.4, 55.2 and $49 \mathrm{~mm}$. From these five samplings, the first, fourth and fifth were selected (55, 98 and 118 DAS, respectively) due to the higher precipitation volume and analyzed by the following parameters: $\mathrm{pH}$, electrical conductivity (EC), Total Kjeldahl $\mathrm{N}, \mathrm{NO}_{3}^{-}, \mathrm{P}, \mathrm{K}, \mathrm{Cu}, \mathrm{Zn}$ and $\mathrm{Na}$ (APHA, 1998) and quantification of the total volume percolated, which allowed to measure the nutrient losses. The overall schedule of the precipitations, percolated samplings and irrigations is represented in Figure 1. There was only one sampling of runoff material (55 DAS) due to the level of precipitation that occurred (118.2 $\mathrm{mm}$ ), and the same parameters determined for the percolated material were evaluated for this runoff sampling.

\section{Data Analysis}

The experimental design was completely randomized. The data were tested for normality and homoscedasticity of variances and, when necessary, were transformed by Box-Cox, used by Dal Bosco et al. (2008) and Ghafoor et al. (2011). The data were analyzed using the analysis of variance (ANOVA) and the means were compared by a Scott-Knott test at $5 \%$ of probability.

\section{Results and Discussion}

\section{Chemical and physical soil analysis}

There were no significant effects of treatments on physical and chemical soil attributes. However, it is worth discussing several of the results obtained to address the environmental limits recommended by the environmental authority or determined in the literature.

The parameters TP and MAP were higher in the surface layer $(0-10 \mathrm{~cm})$ in all treatments, independently on the sampling time (before or after the crop cycle). However, the MIP increased as the soil depth increased. A comparison of samples taken before and after the experiment was installed revealed more changes in $\mathrm{TP}$ in treatment $\mathrm{T} 3$ : the values increased by $8.44 \%, 3.02 \%$ and $3.00 \%$ in the layers $0-10,10-20$ and $20-30 \mathrm{~cm}$ respectively, from April to November. This increase in soil TP was most influenced by the increase in MAP, and it may be related to the nutrient supply from the SW for the plants and the consequent increase in RL and RV of the crop. According to Reinert et al. (2008), greater root growth stimulates the formation of pores due to the intensification of humidity and drying cycles from 
the root exudates and the formation of aggregates by the action of the roots. The greatest changes in MIP, both before and after the oilseed radish crop, occurred in treatment $\mathrm{T} 2$, with the increase of $3.79 \%$, $4.98 \%$ and $7.89 \%$ in the layers $0-10,10-20$ and 20 $30 \mathrm{~cm}$, respectively. Comparing the MAP of the first and second soil samplings revealed greater increase in the treatment that did not receive irrigation (T1): $3.00 \%, 19.00 \%$ and $18.00 \%$ for the first, second and third layers, respectively.

The lowest value of Ds was observed in the $0-10 \mathrm{~cm}$ layer $\left(1.08 \mathrm{~g} \mathrm{~cm}^{-3}\right.$ and $\left.1.11 \mathrm{~g} \mathrm{~cm}^{-3}\right)$, and the highest densities occurred in the subsurface layers $\left(1.13 \mathrm{~g} \mathrm{~cm}^{-3}\right.$ and $\left.1.15 \mathrm{~g} \mathrm{~cm}^{-3}\right)$. This lower density of the surface layer was also observed by Genro Júnior, Reinert e Reichert (2004) in an oxisol and could be related to the greater root density and higher organic matter contents in the topsoil.

From Tables 1 and 2, it is possible to visualize the soil chemical analysis from before and after the experiment set up, respectively. The irrigations decreased soil $\mathrm{pH}$, what may be explained by the liberation of hydrogen ions due to nitrification during the growing cycle of oilseed radish, since $\mathrm{NO}_{2}$ and $\mathrm{NO}_{3}$ concentrations were higher in the $\mathrm{T} 2$ and $\mathrm{T} 3$ treatments. However, the lower $\mathrm{pH}$ was not a problem for this crop, which presented higher yields in T2 and T2 treatments (Table 3).

Table 3. Agronomic analysis and nutrients in shoots of oilseed radish crop in rainfed (T1), irrigated (T2) and fertilized with swine wastewater (T3) treatments.

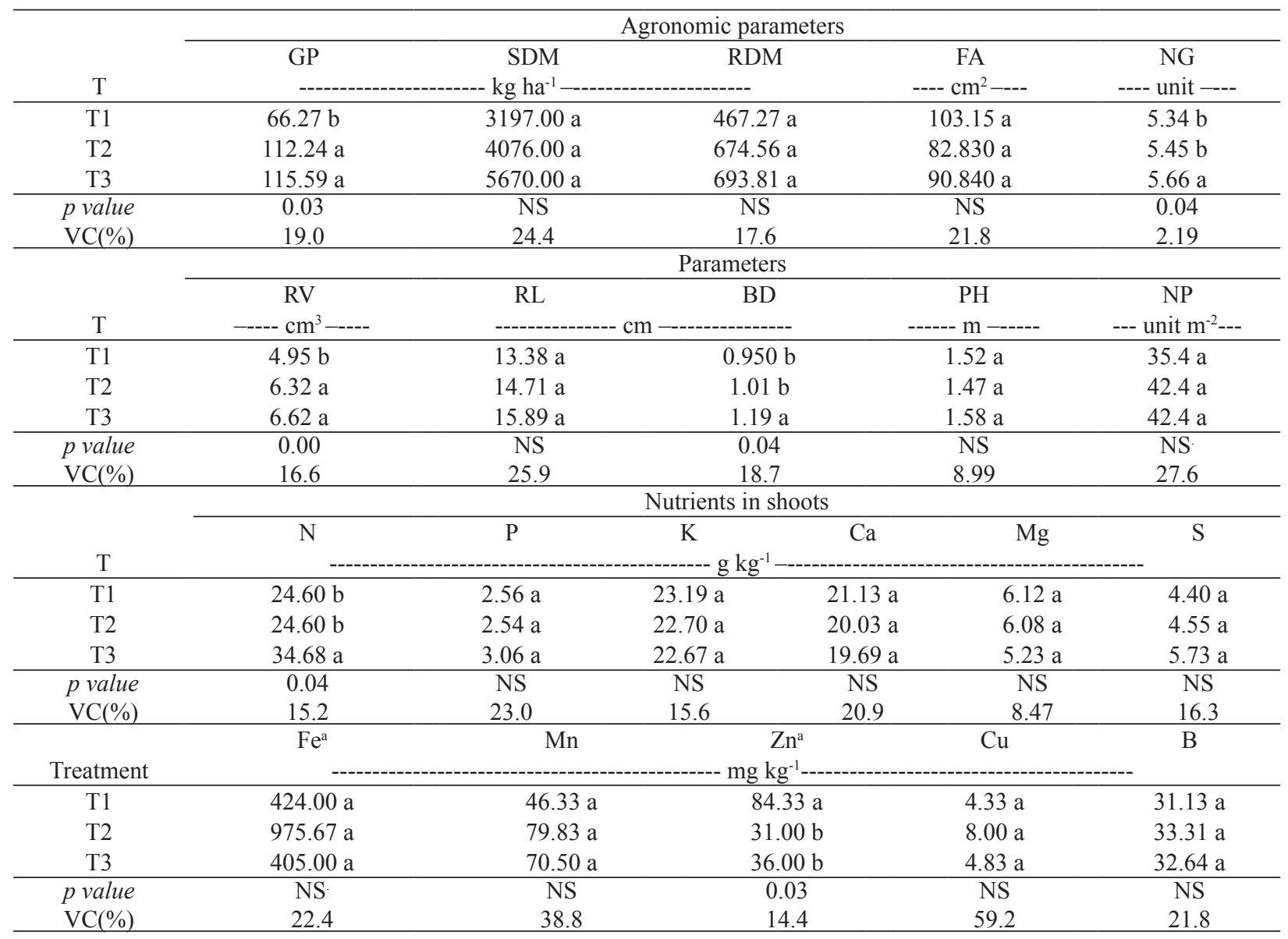

Means followed by the same lower case letter in the column do not differ by Scott-Knott test, at a 5\% significance level.

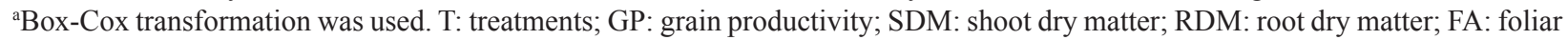
area; NG: number of grains/pod; RV: root volume; RL: root length; BD: basal diameter; PH: plant height; NP: number of plants m². Source: Elaboration of the authors. 
The EC in soil was lower after sowing when compared to the beginning of the experiment, although it did not present a risk to the crop yield, according to Tomé Júnior (1997). The levels of $\mathrm{P}$ in the soil fall within medium to high levels for the most common crops in Brazil (soybean, maize, beans and wheat), ranging from 5.0 to $7.0 \mathrm{mg} \mathrm{dm}^{-3}$ (TOMÉ JÚNIOR, 1997; LANA et al., 2010). The application of SW increased the available $\mathrm{P}$ in the 0-20 cm layer of soil from its initial concentration of $2.9 \mathrm{mg} \mathrm{dm}^{-3}$.

The application of SW did not modify the chemical characteristics of the soil. However, there were considerable changes in $\mathrm{pH}$, exchangeable acidity $(\mathrm{H}+\mathrm{Al}), \mathrm{Al}, \mathrm{K}, \mathrm{Mg}, \mathrm{m} \%, \mathrm{P}, \mathrm{N}_{\text {total }}, \mathrm{NO}_{3}+\mathrm{NO}_{2}$ and inorganic $\mathrm{N}$ between the soil samples collected before and after the experiment.

Biomass, agronomic indices and nutrients in the shoots

The application of SW increased all values for production components, except FA, in comparison with the rainfed treatment (Table 3). Significant effects were observed for GP, NG, RV, BD and concentrations of $\mathrm{N}$ and $\mathrm{Zn}$ in the phytomass. The production of oilseed radish grains (66.270 to 115.59 $\mathrm{kg} \mathrm{ha}^{-1}$ ) was less than expected (300 to $450 \mathrm{~kg} \mathrm{ha}^{-1}$ ) (DERPSCH, 1992; CALEGARI et al., 1993). The low grain yield in this study could be explained by the plant felling down (lodging) during intense precipitation and due to the frosts that occurred one month before the drying of the pods. However, irrigation benefited the GP, as seen by the $69.40 \%$ and $74.40 \%$ of increase in the treatments with water and SW, respectively, over the rainfed treatment. These results corroborate other studies in which there was an increase in grain production associated with the application of SW (CERETTA et al., 2005; COSTA et al., 2007; CRUZ et al., 2008).
In the treatment irrigated with water, DMS increased 27.50\%. Crusciol et al. (2005) found a SDM yield of 2,938 $\mathrm{kg} \mathrm{ha}^{-1}$ with the cultivar Selentina of oilseed radish when sowing was conducted over bean straw in an area with four years of no-tillage system. Lima etal. (2007), studying the same cultivar used in this work observed a SDM production of $5,480 \mathrm{~kg} \mathrm{ha}^{-1}$. There were RDM increases of $44.40 \%$ and $48.50 \%$ in the plants cultivated with water and SW, respectively, compared to plants cultivated in the rainfed treatment. Higher values of RV were observed in $\mathrm{T} 3$ and $\mathrm{T} 2$ if compared with $\mathrm{T} 1$, which were directly associated with the higher production of RDM, showing the affect of irrigation in those treatments.

Regarding the concentration of nutrients in the plants treated with SW, a $41 \%$ increase of $\mathrm{N}$ was observed, but the other nutrients were not affected, suggesting that the SW applied adds more nutrients to the system than crop demands (DURIGON et al., 2002), which might leachate. Calegari (1990) and Crusciol et al. (2005) found $\mathrm{N}$ values for oilseed radish crop of $19.69 \mathrm{~g} \mathrm{Kg}^{-1}$ and $29.6 \mathrm{~g}$ $\mathrm{Kg}^{-1}$, respectively, both lower than detected in $\mathrm{T} 3$. The higher level of $\mathrm{N}$ found in $\mathrm{T} 3$ treated plants highlights the ability of this species to recycle $\mathrm{N}$ and immobilize it as straw for further release to other crops. Oilseed radish may also be a valuable recycler of other nutrients, such as $\mathrm{P}$ and $\mathrm{Mg}$, as the concentrations of these nutrients were greater than or equal to those found for other cultivars of oilseed radish and other species of cover plants such as vetch (Vicia sativa L.), black oats (Avena strigosa) and crotalaria (Crotalaria juncea) (GIACOMINI et al., 2003; MENEZES; LEANDRO, 2004; CRUSCIOL et al., 2005).

\section{Nutrient losses by runoff}

Table 4 shows that the application of SW increased $\mathrm{EC}, \mathrm{NO}_{3}{ }^{-}$, total $\mathrm{P}, \mathrm{K}$ and $\mathrm{Mn}$ in the surface runoff. 
Table 4. Analysis of the runoff and percolated material during cultivation of oilseed radish crop in rainfed (T1), irrigated (T2) and fertilized with swine wastewater (T3) treatments.

\begin{tabular}{|c|c|c|c|c|c|c|c|c|c|c|}
\hline \multirow[b]{2}{*}{$\mathrm{T}$} & \multicolumn{10}{|c|}{ Runoff parameters } \\
\hline & $\begin{array}{c}\mathrm{pH} \\
\mathrm{CaCl}_{2}\end{array}$ & $\begin{array}{c}\mathrm{EC} \\
\mathrm{dS} \mathrm{m}^{-1}\end{array}$ & Total N & $\mathrm{NO}_{3}^{-}$ & $\mathrm{P}$ & $\mathrm{K}$ & $\mathrm{Na}$ & $\mathrm{Cu}$ & $\mathrm{Zn}$ & Mn \\
\hline $\mathrm{T} 1$ & 6.93 & $0.021 b$ & 2.80 & $1.07 \mathrm{~b}$ & $0.016 b$ & $4.04 \mathrm{~b}$ & 14.54 & 0.00 & 0.03 & $0.00 \mathrm{~b}$ \\
\hline $\mathrm{T} 2$ & 7.21 & $0.007 \mathrm{~b}$ & 2.30 & $2.57 \mathrm{~b}$ & $0.017 b$ & $3.05 b$ & 13.84 & 0.00 & 0.06 & $0.03 b$ \\
\hline $\mathrm{T} 3$ & 7.40 & $0.041 \mathrm{a}$ & 7.56 & $8.63 \mathrm{a}$ & $0.049 \mathrm{a}$ & $6.15 \mathrm{a}$ & 19.41 & 0.00 & 0.13 & $0.56 \mathrm{a}$ \\
\hline$p$ value & NS & 0.02 & NS & 0.02 & 0.00 & 0.02 & NS & NS & NS & 0.00 \\
\hline $\mathrm{VC}(\%)$ & 3.37 & 47.0 & 57.4 & 59.6 & 27.8 & 21.3 & 21.3 & 57.4 & 59.6 & 27.8 \\
\hline \multirow[b]{2}{*}{$\mathrm{T}$} & \multicolumn{10}{|c|}{ Percolation parameters } \\
\hline & $\begin{array}{c}\mathrm{pH} \\
\mathrm{CaCl}_{2} \\
\end{array}$ & $\begin{array}{c}\mathrm{EC} \\
\mathrm{dS} \mathrm{m}^{-1} \\
\end{array}$ & Total $\mathrm{N}^{\mathrm{a}}$ & $\mathrm{NO}_{3}^{-\mathrm{a}}$ & $\mathrm{P}$ & $\begin{array}{c}\mathrm{K}^{\mathrm{a}} \\
---\mathrm{m \xi}\end{array}$ & $\mathrm{Na}$ & $\mathrm{Cu}^{\mathrm{a}}$ & $\mathrm{Zn}^{\mathrm{a}}$ & $\mathrm{Mn}^{\mathrm{a}}$ \\
\hline $\mathrm{T} 1\left(1^{\mathrm{st}}\right)$ & 6.65 & $0.104 a$ & $1.93 \mathrm{bA}$ & $0.50 \mathrm{a}$ & $0.017 \mathrm{aA}$ & $6.67 \mathrm{bA}$ & $4.00 \mathrm{bA}$ & $0.00 \mathrm{aA}$ & $1.95 \mathrm{aA}$ & $0.90 \mathrm{bA}$ \\
\hline $\mathrm{T} 2\left(1^{\mathrm{st}}\right)$ & 6.60 & $0.0804 \mathrm{a}$ & $4.28 \mathrm{aA}$ & $0.83 \mathrm{a}$ & $0.016 \mathrm{aA}$ & $9.85 \mathrm{aA}$ & $4.35 \mathrm{bA}$ & $0.00 \mathrm{aA}$ & $1.65 \mathrm{bA}$ & $1.03 \mathrm{aA}$ \\
\hline $\mathrm{T} 3\left(1^{\mathrm{st}}\right)$ & 6.82 & $0.126 \mathrm{a}$ & $6.30 \mathrm{aA}$ & $2.50 \mathrm{a}$ & $0.017 \mathrm{aA}$ & $9.14 \mathrm{aA}$ & $4.79 \mathrm{aA}$ & $0.14 \mathrm{aA}$ & $1.40 \mathrm{bA}$ & $1.10 \mathrm{aA}$ \\
\hline $\mathrm{T} 1\left(4^{\text {th }}\right)$ & 6.67 & $0.10 \mathrm{a}$ & $1.87 \mathrm{aA}$ & $0.10 \mathrm{a}$ & $0.005 \mathrm{aB}$ & $3.07 \mathrm{bB}$ & $3.28 \mathrm{aB}$ & $0.00 \mathrm{bA}$ & $0.04 \mathrm{aB}$ & $0.02 \mathrm{aB}$ \\
\hline $\mathrm{T} 2\left(4^{\mathrm{th}}\right)$ & 6.71 & $0.087 \mathrm{a}$ & $0.78 \mathrm{aA}$ & $0.10 \mathrm{a}$ & $0.005 \mathrm{aB}$ & $5.40 \mathrm{aB}$ & $3.65 \mathrm{aB}$ & $0.00 \mathrm{bA}$ & $0.07 \mathrm{aB}$ & $0.02 \mathrm{aB}$ \\
\hline $\mathrm{T} 3\left(4^{\text {th }}\right)$ & 6.89 & $0.116 \mathrm{a}$ & $3.27 \mathrm{aA}$ & $0.87 \mathrm{a}$ & $0.006 \mathrm{aB}$ & $4.85 \mathrm{aB}$ & $4.05 \mathrm{aB}$ & $0.24 \mathrm{aA}$ & $0.15 \mathrm{aB}$ & $0.05 \mathrm{aB}$ \\
\hline $\mathrm{T} 1\left(5^{\text {th }}\right)$ & 6.74 & $0.097 b$ & $2.72 \mathrm{aA}$ & $0.17 \mathrm{~b}$ & $0.005 \mathrm{aB}$ & $3.91 \mathrm{aB}$ & $3.04 \mathrm{bB}$ & $0.01 \mathrm{aA}$ & $0.05 \mathrm{aB}$ & $0.00 \mathrm{aC}$ \\
\hline $\mathrm{T} 2\left(5^{\text {th }}\right)$ & 6.69 & $0.078 \mathrm{~b}$ & $1.87 \mathrm{aA}$ & $0.27 \mathrm{~b}$ & $0.005 \mathrm{aB}$ & $3.69 \mathrm{aC}$ & $3.27 \mathrm{bB}$ & $0.02 \mathrm{aA}$ & $0.08 \mathrm{aB}$ & $0.00 \mathrm{aB}$ \\
\hline $\mathrm{T} 3\left(5^{\mathrm{th}}\right)$ & 6.87 & $0.13 \mathrm{a}$ & $4.36 \mathrm{aA}$ & $4.33 \mathrm{a}$ & $0.007 \mathrm{aB}$ & $4.10 \mathrm{aB}$ & $4.50 \mathrm{aA}$ & $0.01 \mathrm{aB}$ & $0.12 \mathrm{aB}$ & $0.00 \mathrm{aB}$ \\
\hline $\mathrm{T}$ & NS & 0.00 & 0.00 & 0.01 & 0.01 & 0.01 & 0.00 & 0.02 & NS & NS \\
\hline $\mathrm{C}$ & NS & NS & NS & 0.03 & 0.00 & 0.00 & 0.00 & NS & 0.00 & 0.00 \\
\hline $\mathrm{T}^{*} \mathrm{C}$ & NS & NS & NS & NS & NS & NS & NS & NS & 0.00 & 0.00 \\
\hline $\mathrm{VC}(\%)$ & 2.44 & 23.3 & 30.7 & 19.7 & 5.62 & 8.21 & 8.50 & 4.31 & 3.44 & 1.82 \\
\hline
\end{tabular}

For runoff parameters, means followed by the same lower case letter in the column do not differ by Scott-Knott test, at $5 \%$ significance level. For percolation parameters, means followed by the same upper case letter between collections and lower case letter between treatments are not different by Scott-Knott test, at a 5\% significance level. a Box-Cox transformation was used; VC: variation coefficient; T: treatments; $1^{\text {st: }}: 1^{\text {st }}$ percolation sampling; $4^{\text {th }}: 4^{\text {th }}$ percolation sampling; $5^{\text {th }}: 5^{\text {th }}$ percolation sampling.

Source: Elaboration of the authors.

According to Mantovani, Bernando and Palaretti (2007), the EC found in the runoff in all treatments fell within the low salinity class. In T2, the water level applied through irrigation may have caused a decrease in the EC of the runoff material, which would make the osmotic potential of the soil less negative and thus increase the availability of water.

There was greater concentration of $\mathrm{NO}_{3}^{-}$in T3 due to the high concentration in SW, the effluent application on the top of the soil (without incorporation), and the intense rainfall that occurred one day after irrigation (Figure 1). Furthermore, the higher concentrations of $\mathrm{NO}_{3}^{-}$in the surface runoff from the soil that received SW might be associated with the hot and humid climatic conditions of the region, which favor the nitrification. Nitrogen usually has a great mobility in the soil especially in its $\mathrm{NO}_{3}{ }^{-}$form, which tends to leachate. However, in this study, the levels of both total $\mathrm{N}^{-}$and $\mathrm{NO}_{3}^{-}$in the runoff material for $\mathrm{T} 3$ was almost three times higher than the levels for $\mathrm{T} 1$ and $\mathrm{T} 2$, which deserve special attention. In accordance to Bertol et al. (2005), it is required some cautions to keep the nutrient supply nearby the plants roots avoiding the $\mathrm{NO}_{3}^{-}$transport to sensitive places, as water bodies.

$\mathrm{P}$ had a higher loss to water through surface runoff in T3, approximately $210 \%$ more than in T1 and T2. This singular loss was equivalent to $4.5 \%$ of the $\mathrm{P}$ applied to T3. It is worth noting the pollution potential of total $\mathrm{P}$ via surface runoff from the soil 
of the oilseed radish crop resulting from application of SW, especially with respect to the eutrophication of bodies of water.

The concentration of $\mathrm{K}$ ion was also higher to T3 than T1 and T2. Few authors have studied the effect of $\mathrm{K}$ on surface waters because it is found in a soluble form in manure, becomes available to plants shortly after applied and has a very short residual effect (DURIGON et al., 2002). The element K, however, has great mobility in the soil and it can deslocate $\mathrm{Na}$ from the cation exchange capacity complex to the soil solution. Thus, high amounts of $\mathrm{Na}$ in the soil might reduce the water uptake by plant through the decrease of osmotic potential causing water stress and affect the plant growth and development.

\section{Nutrient losses by percolation}

There was a significant effect of treatment for $\mathrm{EC}, \mathrm{NO}_{3}{ }^{-}$and $\mathrm{Cu}$ (Table 4 ) in the percolated samples.

The highest volume of percolation for all samplings occurred in T1, followed by $\mathrm{T} 2$ and $\mathrm{T} 3$, with the exception of the first collection, in which the volume of T3 was higher than that of T2 and lower than that of T1. This low volume of percolation observed in $\mathrm{T} 3$ and directly related to the precipitation volume (Figure 1) might be due to the action of SW in sealing the soil surface. The treatment may have obstructed the macro and micropores thereby reducing the infiltration rates (DAL BOSCO, 2007; BERTOL et al., 2005). Another hypothesis for this observation is the manure hydrophobic effect (MORI, 2009). In addition, oilseed radish showed excellent agronomic characteristics in $\mathrm{T} 3$, with greater surface plant density, higher dry mass and grain production, development of more robust roots and more accentuated basal diameter than in the other treatments (Table 3). This development would have promoted increased rates of evapotranspiration and water absorption by the plants, reducing the volume of water that percolated through soil.
In the first collection, which followed the greatest precipitation event, $59 \%$ of the total precipitated volume was percolated in $\mathrm{T} 1$. In $\mathrm{T} 2$ and $\mathrm{T} 3$, the total precipitated volumes percolated were $25 \%$ and $34 \%$, respectively. These differences among treatments suggest the possible impact of nonpoint source pollution through percolation on a larger scale, such as watershed (DAL BOSCO, 2007).

According to Table 4, there were significant differences in EC between the treatments in the fifth collection. Although, if it is considered the total volume of percolated material which was greater for T1 (Figure 1), the total salt lost were $13.85 \mathrm{~g}, 7.24$ $\mathrm{g}$ and $10.74 \mathrm{~g}$ for $\mathrm{T} 1, \mathrm{~T} 2$ and $\mathrm{T} 3$ respectively, at the end of the crop cycle.

Total $\mathrm{N}$ was affect by treatments only in the first collection, in which T2 and T3 showed similar values, both higher than T1. During the fourth and fifth samplings, T1 and T2 showed similar $\mathrm{N}$ concentrations, likely due to the high initial concentrations of $\mathrm{N}$ in the soil (Tables 1 and 2). T3 presented a slight high amount of $\mathrm{N}$ compared to the others treatment, showing again the high mobility of the nutrient.

A significant difference in the concentrations of percolated $\mathrm{NO}_{3}{ }^{-}$was only observed in the fifth collection, in which the values found in $\mathrm{T} 1$ and T2 were similar and lower than in T3. However, the concentrations in all collections were less than the limit recommended by Brazilian standards for groundwater (BRASIL, 2008), which is $10 \mathrm{mg} \mathrm{L}^{-1}$. Basso et al. (2005) studying oilseed radish found approximately $17 \mathrm{mg} \mathrm{L}^{-1}$ of $\mathrm{NO}_{3}^{-}$in percolated water after 14 days of applying SW to the soil, demonstrating high mobility of $\mathrm{NO}_{3}^{-}$. The average of $\mathrm{NO}_{3}^{-}$in the present study was approximately $4.3 \mathrm{mg} \mathrm{L}^{-1}$ and occurred in the fifth collection for treatment T3 (12 days after applying SW to the soil). However, Basso et al. (2005) conducted their study on a Paleudalf soil, in which the level of sand reaches $530 \mathrm{~g} \mathrm{~kg}^{-1}$. Sandy soils or soils with higher concentrations of sand retain less $\mathrm{NO}_{3}^{-}$because they 
have lower cation exchange capacity (CEC) due to the less silt, clay and organic matter content.

The total $\mathrm{P}$ in the percolated material (Table 4) demonstrates that the risk of $\mathrm{P}$ contamination is more prevalent in periods with more intense precipitation (first collection), independent of the SW application to the soil (QUINTON; CATT; HESS, 2001). The concentrations of $\mathrm{P}$ percolated are lower than 0.2 to $0.3 \mathrm{mg} \mathrm{L}^{-1}$, cited by Basso et al. (2005) as critical for percolated water.

The Brazilian environmental authority has established maximum values of $0.1,200,0.1,2.00$ and $5.00 \mathrm{mg} \mathrm{L}^{-1}$ for $\mathrm{Mn}, \mathrm{Na}, \mathrm{Cu}$ and $\mathrm{Zn}$, respectively, in groundwater for human consumption (BRASIL, 2008). The values found in the present study do not pose a threat to human consumption, except Mn in the first collection. Overall, the application of SW did not accumulate $\mathrm{Mn}$ in the percolated material, which demonstrates that the greatest loss of nutrients occurred due to the higher intensity precipitation. Besides that, the soil presents naturally high Mn concentration, which can be mobilized mostly by high $\mathrm{pH}$ values.

It is worth noting that, for the first collection, precipitation occurred one day after fertigation (Figure 1), which could have contributed to the increase of the levels of $\mathrm{P}, \mathrm{K}, \mathrm{Na}, \mathrm{Cu}, \mathrm{Zn}$ and $\mathrm{Mn}$ in the percolated material. Bertol et al. (2005) explained that SW is likely to penetrate the soil and is less prone to removal and transport if more time elapses between fertigation and precipitation events. Furthermore, the greater absorption of nutrients by oilseed radish during the blooming phase, approximately 120 DAS (DERPSCH, 1992), may also have influenced the lower amount of nutrients leached in the fourth and fifth samplings (98 and 118 DAS) relative to the first sampling (55 DAS).

\section{Conclusions}

The application of SW led to a greater agronomic quality of the oilseed radish crop (grain yield, root volume, basal volume and number of grains per pod) in comparison with the rainfed treatment. Over the long term, the generation of nonpoint source pollution in the environment due to effluent application must be considered $\left(\mathrm{NO}_{3}^{-}, \mathrm{P}, \mathrm{K}, \mathrm{Mn}\right.$ and total salts in surface runoff and $\mathrm{NO}_{3}^{-}, \mathrm{Na}$ and $\mathrm{Cu}$ in percolated water). Moreover, the precipitation occurred one day after fertigation contributed to the increase of $\mathrm{P}, \mathrm{K}, \mathrm{Na}, \mathrm{Cu}, \mathrm{Zn}$ and $\mathrm{Mn}$ levels in the percolated material, indicating that is important to consider the management of the effluent disposed on soil. More researches might be done to study the affects of effluents in the quality of oil seeds to produce biofuel from oilseed radish crop.

\section{Acknowledgment}

The authors gratefully acknowledge to $\mathrm{CNPq}$ (National Counsel of Technological ans Scientific Development), CAPES (Coordination for the Improvement of Higher Education Personnel), UNIOESTE (Western Paraná State University) and PGEAGRI (Post-Graduation in Agricultural Engineering).

\section{References}

ABOUKHALED, A.; ALFARO, J. F.; SMITH, M. Los lisímetros. Roma: FAO, 1986. 60 p. (Estudos FAO, irrigação e drenagem, 39).

AMERICAN PUBLIC HEALTH ASSOCIATION APHA. Standard methods for the examination of water and wastewater. 20. ed. Washington: APHA, AWWA, WEF, 1998.

BASSO, C. J.; CERETTA, C. A.; DURIGON, R.; POLETTO, N.; GIROTTO, E. Dejeto líquido de suínos: II - perdas de nitrogênio e fósforo por percolação no solo sob plantio direto. Revista Ciência Rural, Santa Maria, v. 35 , n. 6, p. 1305-1312, 2005.

BAUMGARTNER, D.; SAMPAIO, S. C.; SILVA, T. R. da; TEO, C. R. P. A.; VILAS BOAS, M. A. Reúso de águas residuárias da piscicultura e da suinocultura na irrigação da cultura da alface. Revista de Engenharia Agrícola, Jaboticabal, v. 27, n. 1, p. 152-163, 2007. 
BENINCASA, M. M. P. Análise de crescimento de plantas: noções básicas. Jaboticabal: FUNEP, 2003. 42 p.

BERTOL, O. J.; RIZZI, N.; FAVARETTO, N.; LAVORANTI, O. J. Perdas de nitrogênio via superfície e subsuperfície em sistema de semeadura direta. Engenharia Florestal, Curitiba, v. 35, n. 3, p. 429-442, 2005.

BRASIL. Ministério do Meio Ambiente. Conselho Nacional do Meio Ambiente (CONAMA). Resolução $n^{\circ}$ 396, de 03 de abril de 2008. Dispõe sobre a classificação e diretrizes ambientais para o enquadramento das águas subterrâneas e dá outras providências. Diário Oficial [da] União, Brasília, 07 abr. 2008, Seção 1, p. 64-68.

Presidência da República. Ministério da Casa Civil. Lei $\mathrm{n}^{\circ} 11.097$, de 13 de janeiro de 2005. 2005. Dispõe sobre a introdução do biodiesel na matriz energética brasileira e dá outras providências. Diário Oficial [da] União, Brasília, 14 jan. 2005, Seção 1, p. 8-9.

CALEGARI, A.; MORDARDO, A.; BULISANI, E. A.; COSTA, M. B. B. da; MIYASAKA, S.; AMADO, T. J. C. Aspectos gerais da adubação verde. In: COSTA, M. B. B. da. (Coord.). Adubação verde no sul do Brasil. 2. ed. Rio de Janeiro: AS-PTA, 1993. p. 307-324.

CALEGARI, A. Plantas para adubação verde de inverno no sudoeste do Paraná. Londrina: IAPAR, 1990. 37 p.

CERETTA, C. A.; BASSO, C. J.; VIEIRA, F.; HERBES, M. Produtividade de grãos de milho, produção de matéria seca e acúmulo de nitrogênio, fósforo e potássio na rotação aveia preta/milho/nabo forrageiro com aplicação de dejetos líquidos de suíno. Revista Ciência Rural, Santa Maria, v. 35, n. 6, p. 1287-1295, 2005.

COSTA, C. C.; CAMPOS, C. M. M.; REZENDE, F. C.; CUSTÓDIO, T. N. Produtividade de feijão-vagem fertirrigado com água residuária de suinocultura após tratamento anaeróbio. Revista Agrogeoambiental, Inconfidentes, v. 1, n. 3, p. 19-27, 2007.

CRUSCIOL, C. A. C.; COTTICA, R. L.; LIMA, E. do V.; ANDREOTTI, M.; MORO, E.; MARCON, E. Persistência de palhada e liberação de nutrientes do nabo forrageiro no plantio direto. Pesquisa Agropecuária Brasileira, Brasília, v. 40, n. 2, p. 161-168, 2005.

CRUZ, M. do C. M. da; RAMOS, J. D.; OLIVEIRA, D. L. de; MARQUES, V. B.; HAFLE, O. M. Utilização de água residuária de suinocultura na produção de mudas de maracujazeiro-azedo cv redondo amarelo. Revista Brasileira de Fruticultura, Jaboticabal, v. 30, n. 4, p. 1107-1112, 2008.

DAL BOSCO, T. C. Poluição difusa decorrente da aplicação de água residuária da suinocultura em solo cultivado com soja sob condições de chuva simulada. 2007. Dissertação (Mestrado em Engenharia Agrícola) - Universidade Estadual do Oeste do Paraná. Cascavel.

DAL BOSCO, T. C.; SAMPAIO, S. S.; OPAZO, M. A. U.; GOMES, S. D.; NOBREGA, L. H. P. Aplicação de água residuária de suinocultura em solo cultivado com soja: cobre e zinco no material escoado e no solo. Engenharia Agrícola, Jaboticabal, v. 28, n. 4, p. 699-709, 2008.

DARTORA, V.; PERDOMO, C. C.; TUMELERO, I. L. Manejo de desejo de suínos. Concórdia/Porto Alegre: BIPERS. Embrapa Suínos e Aves e EMATER/ RS - BIPERS, 1998. ano 7, 33 p. (Boletim Informativo Pesquisa \& Extensão, n. 11).

DERPSCH, R. Plantas para adubação verde de inverno. Londrina: IAPAR, 1992. 82 p.

DOBLINSKI, A. F; SAMPAIO, S. C.; SILVA, V. R. da; NÓBREGA, L. H. P.; GOMES, S. D.; DAL BOSCO, T. C. Nonpoint source pollution by swine farming wastewater in bean crop. Revista Brasileira de Engenharia Agrícola e Ambiental, Campina Grande, v. 14, n. 1, p. 87-93, 2010.

DOMINGOS, A. K.; SAAD, E. B.; WILHELM, H. M.; RAMOS, L. P. Optimization of the ethanolysis of Raphanus sativus (L. Var.) crude oil applying the response surface methodology. Bioresource Technology, Amsterdã, v. 99, n. 6, p. 1837-1845, 2008.

DURIGON, R.; CERETTA, C. A.; BASSO, C. J.; BARCELlOS, L. A. R.; PAVINATO, P. S. Produção de forragem em pastagem natural com o uso de esterco líquido de suínos. Revista Brasileira Ciência do Solo, Viçosa, v. 26, n. 2, p. 983-992, 2002.

EMPRESA BRASILEIRA DE PESQUISA AGROPECUÁRIA - EMBRAPA. Centro Nacional de Pesquisa de Solos. Manual de métodos de análise de solos. 2. ed. Rio de Janeiro: Embrapa, 1997.

GATIBONI, L. C.; BRUNETTO, G.; KAMINSKI, J.; RHEINHEIMER, D. S.; CERETTA, C. A; BASSO, C. J. Formas de fósforo no solo após sucessivas adições de dejeto líquido de suínos em pastagem natural. Revista Brasileira de Ciência do Solo, Viçosa, MG, v. 32, n. 4, p. 1753-1761, 2008.

GENRO JÚNIOR, S. A.; REINERT, D. J.; REICHERT, J. M. Variabilidade temporal da resistência à penetração de um Latossolo argiloso sob semeadura direta com rotação de culturas. Revista Brasileira de Ciência do Solo, Viçosa, MG, v. 28, n. 3, p. 477-484, 2004.

GHAFOOR, A.; JARVIS, N. J.; THIERFELDER, T.; STENSTROM, J. Measurements and modeling of pesticide persistence in soil at the catchment scale. Science of the Total Environment, Amsterdan, v. 409, n. 10, p. 1900-1908, 2011. 
GIACOMINI, S. J.; AITA, C.; VENDRUSCOLO, E. R. O.; CUBILlA, M.; NICOLOSO, R. S.; FRIES, M. R. Matéria seca, relação $\mathrm{C} / \mathrm{N}$ e acúmulo de Nitrogênio, Fósforo e Potássio em misturas de plantas de cobertura de solo. Revista Brasileira Ciência do Solo, Viçosa, v. 27, n. 2, p. 325-334, 2003.

INSTITUTO AGRONÔMICO DO PARANÁ - IAPAR. Cartas climáticas do Paraná. In: CAVIGLIONE, J. H.; KIIHL, L. R. B.; CARAMORI, P. H.; OLIVEIRA, D. Londrina: IAPAR, 2000. Disponível em: $<$ http://www.iap ar.br/modules/conteudo/conteudo.php?co nteudo=677 $>$. Acesso em: 24 jan. 2011.

LANA, M. do C. Análise química de solo e tecido vegetal: práticas de laboratório. Cascavel: EDUNIOESTE, 2010. $130 \mathrm{p}$.

LIMA, D. J.; ALDRIGHI, M.; SAKAI, R. K.; SOLIMAN, E. P.; MORAES, W. da S. Comportamento do nabo forrageiro (Raphanus sativus L.) e da nabiça (Raphanus raphanistrum L.) como adubo verde. Agropecuária Tropical, Goiânia, v. 37, n. 1, p. 60-63, 2007.

MAGGI, C. F.; FREITAS, P. S. L. de; SAMPAIO, S. C.; DIETER, J. Lixiviação de nutrientes em solo cultivado com aplicação de água residuária de suinocultura. Revista Brasileira de Engenharia Agrícola e Ambiental, Campina Grande, v. 15, n. 2, p. 170-177, 2011.

MALAVOLTA, E.; VITTI, G. C.; OLIVEIRA, S. Avaliação do estado nutricional das plantas. 2. ed. Piracicaba: Potafós, 1997. 319 p.

MANTOVANI, E. C.; BERNANDO, S.; PALARETTI, L. F. Irrigação: princípios e métodos. 2. ed. Viçosa: Ed. UFV, 2007. 358 p.

MENEZES, L. A. S.; LEANDRO, W. M. Avaliação de espécies de coberturas do solo com potencial de uso em sistema de plantio direto. Pesquisa Agropecuária Tropical, Goiânia, v. 3, n. 34, p. 173-180, 2004.

MORI, H. F. Perda de água, solo e fósforo com aplicação de dejeto líquido bovino em latossolo sob plantio direto e com chuva simulada. Revista Brasileira Ciências do Solo, Viçosa, MG, v. 33, n. 1, p. 189-198, 2009.
OLSEN, S. R.; SOMMERS, L. E. Phosphorus. In: PAGE, A. L.; MILLER, R. H.; KEENEY, D. R. (Ed.). Methods of soil analysis: chemical and microbiological properties. $2^{\text {nd }}$ ed. Wisconsin: American Society of Agronomy, Inc., 1982. p. 403-430.

QUINTON, J. N.; CATT, J. A.; HESS, T. M. The selective removal of phosphorus from soil: is event size important? Journal of Environmental Quality, Madison, v. 30, n. 2, p. 538-545, 2001.

RAIJ, B. van; ANDRADE, J. C. de; CANTARELLA, H.; QUAGGIO, J. A. Análise química para avaliação da fertilidade de solos tropicais. Campinas: Instituto Agronômico, 2001. 285 p.

REINERT, D. J.; ALBUQUERQUE, J. A.; REICHERT, J. M.; AITA, C.; ANDRADA, M. M. C. Limites críticos de densidade do solo para o crescimento de raízes de plantas de cobertura em argissolo vermelho. Revista Brasileira de Ciência do Solo, Viçosa, MG, v. 32, n. 5, p. 1805-1816, 2008.

SILVA, P. R. F. da; FREITAS, T. F. S. de. Biodiesel: o ônus e o bônus de produzir combustível. Ciência Rural, Santa Maria, v. 38, n. 3, p. 843-851, 2008.

SMITH, D. R.; OWENS, P. R.; LEYTEM, A. B.; WARNEMUEND, E. A. Nutrient losses from manure and fertilizer applications as impacted by time to first runoff event. Environmental Pollution, Maryland Heights, v. 147, n. 1, p. 131-137, 2007.

SOIL SURVEY STAFF. Soil taxonomy: a basic of soil classification for making and interpreting soil surveys. $2^{\text {nd }}$ ed. Washington: USDA, 1999. Natural Resources Conservation Service. US Department of Agriculture Handbook 436.

TOMÉ JÚNIOR, J. B. Manual para interpretação de análise de solo. Guaíba: Agropecuária, 1997. 247 p. 
